http://dx.doi.org/10.7833/116-1-1275

\title{
'PENTECOSTAL THEOLOGY' AS CONTRADICTIO IN TERMINIS: A PERSPECTIVE ON THE PAST AND PRESENT
}

\author{
Marius Nel \\ North West University
}

\section{Abstract}

The Pentecostal movement, especially in its early days, has been accused of antiintellectualism and a lack of a developed theological tradition, and it is conceded that it is justifiably so. In the early movement, to speak of 'Pentecostal Theology' represented a contradiction in terminis. It is argued in the first part that Pentecostalism's anti-intellectualism should be understood (and justified) as a historical phenomenon, in terms of the contributions of several prominent Pentecostal leaders, Richard Spurling, William Parham, William Seymour and David Myland. The conclusion is that the movement's anti-intellectualism served as a reaction to what it perceived to be the dangers that 'theology' posed, as represented by creedalism and formalism. Against this, Pentecostals emphasised Spirit baptism and the resultant life guided by the Spirit as prerequisites for the development of the believer's spiritual dimension, that might at times stand in contrast to intellectual capabilities and endavours. Its restorationist motive required the Pentecostal movement to return to the experience and power of the earliest Church, driven by its apocalypticeschatological expectation of the imminent second coming of Christ. In the second part, the contemporary Pentecostal movement's stance on 'theology' as well as its theological principles and contributions are described. Although Pentecostals originally made negative remarks about 'theology', today they define it in a specific manner that allow them to take seriously their own brand of theological enterprise. They base their theology on encounters with God through his Spirit, described in terms provided by biblical narratives and leading to a spirituality that occupies the affections as well as the minds of its practitioners. Although their theology has traditional elements that they share with other traditions, Pentecostals' spirituality requires that their theology should be based on first-hand experiences with God, resulting in some doctrines being defined in a manner that differs from other theological traditions. It is concluded that contemporary 'Pentecostal Theology' does not represent a contradictio in terminis any more.

Key Words: Pentecostal Theology; Anti-intellectualism; Experiential Angle; Hermeneutics; Relational Knowledge

\section{Introduction}

'Pentecostal Theology' has been characterised as a contradiction in terms (Spittler 1983:39) because of its anti-intellectualist stance that presumably disqualifies it from doing theology. This is demonstrated by its repeated negative remarks about the contribution of 'theology' to the life of "the church that lives in dependence on the Holy Spirit" (as Pentecostals perceive themselves). Early Pentecostalism situated itself as a reaction against Modernism with its obsession with logic, academics and science (Enyinnaya 2008:147). Historically 
the movement originated among the poor classes, representing an illiterate, oral and preliterary culture (Hollenweger 1986:5) and justified by the Pentecostal claim that God is now speaking orally and through visions and dreams, instead of through biblical exegesis and exposition, in order to circumvent and denounce Christian intellectualism (Enyinnaya 2008:147). ${ }^{1}$

Early South African Pentecostalism is also characterised by anti-intellectualism based on the historical given of the movement's origin among the marginalised and illiterate who lacked the motivation or skills to engage in intellectual activities and organisations. Its antiintellectualism is also driven by the urgency and determination of Pentecostals to proclaim the gospel of salvation to a world facing the imminent second coming, leaving no time for training and preparation. Early Pentecostals opined that an intellectualisation of the faith was resisting or suppressing the work of the Holy Spirit, while the life of the Spirit and the demands of intellectual labours were seen as opposites that do not readily mix. Its antiintellectuality rests on the observations that Pentecostal spirituality arises from the affections rather than intellectual ability; it is dominated by imagination rather than reason; it operates on the level of oral rather than written discourse; and it is concerned with ongoing, daily revelation of truths in the life of the individual and assembly rather than the revelation of eternal truths, as $\mathrm{Nel}$ (2016:7) illustrates.

It is argued here that Pentecostalism's seeming anti-intellectualism, rather than being an essence of the movement, is in effect the result of its raison d'etre, as explained in its restorationist motif. It intends to restore primitive Christianity that Pentecostals perceived has been polluted by 'theological endeavours' that degenerated into mere creedalism and formalism that characterised the church from the fourth century CE. They argued that history shows the danger how theological reflection can decay and become a potential stumbling block to the free flow of the Spirit because the intellect of believers stands in God's way. They emphasised the necessity of orthopraxy before striving for orthodoxy in the light of the imminent second coming of Christ, and the difficulty of letting go of oneself in order to give control to God while one's mind prevents one from entering the spiritual dimension of the pentecostal baptism (Naňez 2005).

Early Pentecostals did not publish much theological treatises but rather spent their energy in writing devotional articles and sermons. They made better missionaries than theologians, writing pamphlets and tracts, not books and treatises (Spittler 1983:39)., Energetic movements of religious experience, however, are dependent on basic, more systematic presentations of the Christian faith as a foundation which is rooted in a vision of reality as a whole, as Rogers (1981:4) explains. In this article reference is made to authors in the early Pentecostal movement to illustrate their stance on theology and its anti-intellectuality before the contributions that Pentecostal Theology is making are described. Some exponents'contention that charismatic experience does not represent theology can no longer be accepted without qualification, argues Gelpi (1978:21) and Hollenweger (1992:7). ${ }^{2}$

In the first part of the article it is argued that Pentecostalism's anti-intellectualism should be understood (and justified) as a historical phenomenon before a second part refers to its theological principles and the contribution it makes to theological endeavours, concluding that it is no longer possible to speak about anti-intellectualilty in the contemporary movement.

It should be kept in mind that only approximately thirty per cent of the world's population can read.

It must be admitted that some smaller groups within Pentecostalism still shun the term 'theology' and mistrust formal academic enterprises and theological education (Enyinnaya 2008:147). Pentecostal Theology, however, is no longer an oxymoron (Spittler 1985:56-57). 


\section{A Historical Survey of Pentecostalism's Anti-intellectualist Tradition Richard G Spurling as a Precursor to the Pentecostal Movement: Dangers of Creedalism}

Richard G Spurling (1858-1935) ${ }^{3}$ was one of the early leaders of a part of the Pentecostal movement that would eventually evolve into the Church of God with its headquarters in Cleveland, Tennessee. He wrote The Lost Link in 1897 in response to his pre-Azusa Street experiences of Spirit baptism and reworked and published it in 1920 in an expanded form.

Spurling served as a missionary of the Missionary Baptist Church of eastern Tennessee before he left the Baptist tradition in 1884 with his father, apparently because they did not agree with Baptist theology (Tomlinson 1913:173). Father and son joined in 1886 with a group of local Christians to form the Christian Union, with the stated purpose "to restore primitive Christianity and bring about a union of all denominations" (Conn 1988:202). In 1892, the Christian Union joined another fellowship under the leadership of WF Bryant, and in 1896 members of the Christian Union experienced "the power of God" and spoke in unknown languages at a series of revival services (Tomlinson 1913:184). With the advent of the Pentecostal movement, the descendants of this fellowship, the Church of God, would look back at this event that could not be explained at the time and call it the beginning of their church's journey into Pentecostalism (Jacobsen 2003:32).

Spurling's manuscript dated from this era, as a private reflection on these events. It represents an early attempt of a proto-Pentecostal to articulate a theology that reflects the kind of thinking in the movements that preceded and anticipated the Pentecostal movement.

Spurling (1920:23) creates a historical paradigm that he uses to define and justify his own theological position. He describes the historic fall of the church into what he terms creedalism, and argues that the development of every new creed has led consistently to the creation of a new sect or denomination. In contrast, the sign of true faith is love, but this love was diminished because of sectarian strife in the church from the fourth century CE onwards, leading to true faith eventually ceasing to exist. The early church's problems started when the Council of Nicea in $325 \mathrm{CE}$ accepted the Nicene Creed, at the instigation of the emperor Constantine and as part of his attempt to Christianise the Roman Empire and stabilise his reign (Spurling 1920:8, 15-16). Nicea used the creed legalistically to condemn Arius and others as heretics, making it an acceptable practice to expel believers from the fellowship regardless of their love for God and one another. In formulating orthodoxy, Nicea excluded pockets of 'dissident' Christians. The lines between church and state faded and the rule of love for God and neigbour was replaced by the impersonal rule of creeds, leading to a formalist form of religion. In the words of Parham ([1902]1944:66), "the best of creeds are but the sawdust of men's opinions, stuffed in skins and feathers of truth to give them a pleasing and attractive appearance; to draw people into the support of an organised ecclesiasticism, or an individualistic propaganda". Now it became practice for the church to hunt and kill those who maintained another opinion in the name of pure doctrine, the popes in many instances being the chief protagonists (Spurling 1920:23-24). The papal system substituted law and hierarchy for love and equality, the opposite of what the church was supposed to represent. Even many Protestant churches would later succumb to utilising the same violent propensities. The Protestants only tried to reform the creeds to a purer standard (Spurling 1920:36-37); they did not realise the evil origins and intents of the formulation of the creeds as such.

Jacobsen (2006) compiled the most important original writings of early Pentecostals, including Spurling's. 
Only now, in the last days, writes Spurling (1920:39-40), was the church returning to the rule of love again, as a sign of God's promise to restore the church to its original character before the end of the age. In order to avoid orthodoxy again overpowering and disempowering orthopraxy, contemporary believers should make their experience their creed, argues King (1937:1). "Pentecostalism was a protest against the use of religious words without religious experiences to back them up: it was a protest against theological hollowness" (Jacobsen 2006:5). The sign of the new rule of love is the baptism in the Spirit with the sign of speaking in tongues, restoring the essence of what defined the early Church. Spurling thought of the Christian Union as representative of this new drive of the Spirit for the restoration of the original church, as part of the larger Pentecostal movement.

Spurling's Baptist roots can probably account for his emphasis on the spiritual freedom of the individual and criticism of all creeds, characteristic of some Baptist traditions. For instance, James R Graves (1820-1893), an influential Southern Baptist leader, had earlier campaigned for the local autonomy of individual congregations, the rather vague ideal of the 'true church' and opposition to the "power-hungry action of the established church" (Tull 1984:399), providing some of the lenses that Spurling would eventually use to interpret his own experiences. Spurling emphasises love as the ultimate glue for his theological reflections about the restoration of the apostolic church (Jacobsen 2003:33), declaring it to be the greatest gift and leading to Christians having equal democratic rights and privileges to believe and practice their religion in their own way, with everyone living peaceably side by side as equal neigbours and with God as the only ruler (Spurling 1920:12,45). This is the only way to combat the influence exercised by creedalism and its resultant formalism that proliferated since the fourth century $\mathrm{CE}$.

\section{William Parham and the Pentecostal Movement's Eschatological Expectations}

William Fox Parham (1873-1929) established a healing home in 1898 and two years later a Bible school with the intention to revive the 'latter rain' outpouring of the Spirit, on the heels of which would in his opinion follow the premillenial return of Christ. Around the turn of the millennium, Parham and half of his student body of thirty-four were baptised in the Spirit with accompanying speaking in languages, leading eventually to the Azusa Street revival of 1906 (Goff 1988:661). Xenolalic tongues served for Parham as proof of Spirit baptism, making its recipients instant missionaries and prompting the start of the expected global revival (Goff 1988:660).

Parham's ([1902]1944:115-118) theology supposes that the close of the age leading to the second coming of Christ was at hand. It can be decuded from the "signs of the end" that abounded everywhere, such as the Franco-Prussian War, the struggle between England and Ireland, tensions over the Suez Canal, the popularity of Christian Science, spiritualism, hypnotism, occultism, the moral decline of America and the increasing number of Jews returning to Israel. Parham predicted that when delegates of the Jewish Congress meet in Jerusalem and by proclamation declare themselves a restored nation (that happened in 1948), seven years from that day the feet of Jesus Christ would touch the Mount of Olives (Parham [1902]1944:92, 105-111). The present phase of human history would then end with the final seven-year period of warfare, sickness, and death called the 'great tribulation', ending in a thousand-year epoch of godly rule, called the 'millennium'. Parham believed God would 'rapture' or remove some elect Christians from the earth before the tribulation begins although most Christians would remain on earth during the seven-year period and would suffer severely. Subsequent to the millennium, the "great white throne of judgment" would determine the eternal fate of human beings. When the 
wicked had been destroyed (Parham preferred a total annihilation of sinners), the era of endless eternity would begin when God would descend to and live among humanity (Parham [1902]1944:52).

The imminence of the second coming necessitates that Christians spend all their energy and time evangelising the world (Parham [1902]1944:74-78). No time was left for the luxury of amassing wealth or learning. Intellectual capital was wasted in these last days with theological endeavours when believers should rather preach than study. Christians need the "anointing that abideth", giving the recipient special powers to heal the sick and cast our demons. The purpose of the baptism of the Spirit was to take the believer's life and pour it out in service of reaching people with the gospel. It compels believers to share their spiritual gifts and powers with those around them (Parham 1920:63, 66). And the ability to speak in other tongues was a special empowerment for end-time service, especially the endtime work of evangelism. It is the power to witness and communicate the gospel effectively to others. Parham $(1920: 66-67,69)$ describes it as "prophecy expressed in a foreign tongue rather than in one's own native tongue". The urgency of their apocalyptic expectation led Pentecostals to concentrate on the practice of evangelism with the gift of tongues interpreted as an eschatological empowerment for mission. The baptism of the Spirit was a special end-time gift of God (Parham 1920:68), inaugurating the end of the age. Their antipathy toward intellectual endeavours was based on Pentecostals' eschatological expectation of the imminent second coming of Christ.

\section{William Seymour and Azusa Street's Criticism of Theology}

The revival at Azusa Street from 1906 to 1911 functioned as the Grand Central Station in New York City for the Pentecostal movement in Jacobsen's (2003:49) parlance, with almost everyone connected with the early movement having some form of connection with the Los Angeles revival, led by William J Seymour (1870-1922) (Synan 1988:778).

From its inception the Pentecostal movement viewed itself as a critical turning point in the history of the church, as the culmination of the Protestant Reformation and completion of the restoration of the early church. For instance, Seymour (Oct 1906:1) writes that while Martin Luther brought back the doctrine of justification by faith, John Wesley established holiness in the church and Charles Cullis rediscovered divine healing, now was the time for the church to re-experience the baptism in the Spirit that would restore "the original church". The Pentecostal revival was the beginning of the last great end-time revival that would usher in the return of Christ; the goal of the revival was the full restoration of the church (Seymour Dec 1906:1).

The movement was convinced that traditional theology as defined by Roman Catholics and Protestants alike was suspect, serving as a potential stumbling block to the free flow of the Spirit and pentecostal faith because it accommodated the intellect of the believer that stood in the way of the Spirit wishing to meet human beings in their spirit and affections. Theology thus became something that one needed to overcome before one would encounter God by transcending and incorporating intellectual enterprises. For instance, in April 1907, The Apostolic Faith ${ }^{4}$ (Anonymous Apr 1907:1) declared that the pentecostal message was not revealed to "our great theologians" but to the disenfranchised who humbly came as little babes to receive what the Lord promised to give. The poor were not dependent on their proven intellectual brilliance but came as the "poor in spirit" before God, pleading the

4 Available issues of the magazine of the Azusa Street revival, The Apostolic Faith, is published in Noble (1991). 
blood of Jesus as their only recompense. The experience was that the ordinary and uneducated were more able to receive the Spirit baptism because their intellectual abilities did not trip their faith and they recognised how dependent they were on the sovereign move of God to meet them (Anonymous Sep 1907a:3).

It was not just the case that theology, a feature of the contemporary church, did not bring Pentecost to people; it was also perceived that theological reflection could quench the Spirit, illustrated by the remark that consideration and talking about the work of the Spirit "put straps and bands on the Holy Ghost" (Anonymous Sep 1907b:2). The antidote was to concentrate on the Word: "We are feeding upon the Word which is revealed by the Holy Ghost - the whole Word and nothing but the Word" (Anonymous Sep 1907b:2). While human theology tended to extinguish the Spirit because it consisted of human words, belief and trust in the Word of God led to an encounter with God falling outside the mere intellectual realm.

The trend in the early Pentecostal movement to denigrate theology as mere human attempts was perpetuated for several decades, earning the movement the characterisation as anti-intellectual and overly emotional (Yeung 2011:59). However, this should be qualified to do justice to the movement who also emphasised sound doctrine (Wacker 2001:ix). The first issue of The Apostolic Faith (Sep 1906:2), a magazine published by the Azusa Street Mission (or Apostolic Faith Gospel Mission), declared that this new movement first of all represented the restoration of the faith once delivered to the saints by the apostles, consisting of repentance that consists of sorrow, confession of sins, forsaking of sinful ways, and restitution, faith in Jesus Christ, sanctification as a second work of grace, the baptism with the Spirit including the evidence of speaking in tongues, and healing. The article was probably written by William J Seymour, the leader at Azusa Street, who asserts that God would not forgive a man's sin against another man (gender language used in article) that man should make right himself. The blood of Jesus only covers sins that humans cannot make right. In other cases, restitution should be the chosen way because there is no cheap grace available for believers. The list of doctrines from the earliest days of the Pentecostal movement illustrates its developed theological orientation, focused on pastoral concerns (Naňez 2005:184). The theology of Azusa Street was characterised by its three-step view of the progression of Christian life, from justification to sanctification and Spirit baptism, the identification of the marks that should accompany and follow Spirit baptism, and its emphasis on the imminent return of Christ.

In the early Pentecostal movement there was a tendency to ignore theological differences because of the experiential aspect of Spirit baptism, leaving some with the idea that they could be one in spirit even though they differ in doctrine. Seymour, however, was more practical and acknowledged early on that doctrinal differences that characterised the early movement as a result of its adherents coming from diverse movements such as the holiness movement, pietism, the American Evangelical Awakenings, the Irvingites, the faith healing movement, and John A. Dowie's Zionism would eventually necessitate schisms. ${ }^{5}$ Seymour (Sep 1906:2) writes, "we cannot all be one, except through the word of God". Views contrary to Scripture have to be expunged from the community of believers to avoid 'spiritual fornication'. He underlines the necessity to build clear boundaries of sound theology around the community of faith. Twice Seymour's leadership at Azusa Street was challenged, by Charles Parham and William Durham, and each time doctrinal differences

Sharing its roots with these movements, however, does not allow the equation of Pentecostalism with pietism and fundamentalism, as Vallarie (1983:4-5) purposes (cf. Johns 1998:3). 
were at the heart of the confrontation, and each time Seymour stood up successfully for what he believed to be the essence of the new movement's theology.

What happened in the early movement was that the doctrines of the established denominations, perceived by Pentecostals as that it denied that Spirit baptism could happen in contemporary times or that speaking in tongues served as the initial evidence of this baptism, were branded as victims of 'theology', leading to 'theology' being interpreted in negative terms.

On the other hand, the Pentecostal movement emphasised sound doctrine. Its purpose was to help heal the natural man born into the world lame in intellect, will and affections, in Seymour's (1915:90) terms. The will and affections would be healed by the Spirit but only after sound doctrine helped to heal man's lame mind. And although this was a role for theology that was necessarily limited, it was still necessary and essential.

\section{David Myland and the Danger of the Intellect in Experiencing Pentecostal Baptism}

A last factor that accounts for Pentecostalism's perceived anti-intellectualist stance has to do with its experience of life in the Spirit. David W Myland (1858-1943) did not visit Azusa Street himself at any stage. He served in the Methodist church before joining the Christian Alliance, a group that advocated divine healing. Around 1890 he received what he termed "a special anointing of the Spirit" while working in his library, causing him to sing and say things in a language he did not understand. At a later stage and in light of what he learnt about the Pentecostal revival at Azusa Street, he interpreted this experience as the beginning of his pentecostal baptism and his singing as a form of speaking in tongues (Myland 1910:192-194; Robinson 1988:632). He had heard about the Azusa Street events and it provided him with the language to describe his own experiences. He now joined the Christian and Missionary Alliance, operated a healing home in Cleveland, and edited a journal, the Christian Messenger. At this time he was burnt badly when a gas stove exploded and he experienced healing and accompanying it, the residue of the pentecostal experience (Myland 1910:64; 1911:169). The Christian and Missionary Alliance decided in 1912 to cut its ties with the Pentecostal movement and Myland left the group to help found the Apostolic Christian Association as a way of returning to the Pentecostal movement.

In his 1910 publication, The Latter Rain Covenant, he describes the pentecostal or charismatic experience of early Pentecostals in terms of 'spiritual fullness' that is graduated and not static. To enter fully into the experience of pentecostal fullness, you "have to have your imagination subdued, your reason adjusted, your perceptions clarified, and your judgment and will sanctified; otherwise, you will be governed, not by knowledge, but by emotion and feeling" (Myland 1910:14-16). And this is what the enemy of the soul wishes to accomplish, he adds, to play on believers' emotions and feelings. In other words, the mind plays an important role in the experience of the pentecostal baptism, but it could easily become a problem when it prevents people from entering the 'spiritual dimension' of the pentecostal baptism. One's intellectual nature can become a stumbling block in opening oneself to the fullness of God. Such 'hard-headed fellows' need to be "crucified at the place of a skull" (referring at the same time to Golgotha and one's intellectual capabilities) and their heads need to be soaked under the influence of the Spirit (Myland 1910:15, 24). For this reason it is necessary for the individual believer to partake in the activities of a group where in unity they flow into the goodness of the Lord, and stiffness and unbelief as the result of an over-active mind depart (Myland 1910:21, 64).

A prerequisite for the experience of pentecostal fullness is that one has to let go of oneself in order to give control to God. This might seem threatening for some people but it 
forms the core of the pentecostal experience, allowing oneself to relax in God's enveloping presence and allow his Spirit to take charge. This experience is like swallowing God liquidified, curing "the worst case of moral and spiritual dyspepsia" (Myland 1910:55-56).

The experience of pentecostal fullness implies that the spiritual nature needs to dominate the psychical or intellectual, and that the intellectual has to be given its divinely appointed place. What is necessary is that all the facets of the human personality work together under God's control. The spiritual and intellectual should be integrated so that one's intellectual capabilities do not hinder the Spirit to set the heart on fire with the sacrificing love of God (Myland 1911:69). When believers only function on the intellectual level they never get into the spiritual dimension, and then their prayers, songs and testimonies happen only in the intellect and never reaches down into the spiritual. The opposite is also true, that if one remains in the spiritual dimension alone one could easily land up being governed by emotions and feelings, negating reason and knowledge. If service of God is only connected to the spiritual dimension, it leads to fanaticism; if in the intellectual dimension only it results in formalism (Myland 1910:13). What is needed is a balance between the three dimensions of the person, a simultaneously passionate, reasonable, and bodily experience of God (Myland 1910:16).

\section{'Anti-intellectualism' in the Early Pentecostal Movement}

Asamoah-Gyadu (2005:393) acknowledges that although African Pentecostalism has resulted largely from the work of foreign missionaries, indigenous founders and leaders worked in active collaboration with foreign Pentecostal missions. Although they Africanised some of their practices to accommodate the effects of evil caused by demonic spirits and witchcraft (Asamoah-Gyadu 2005:407), issues relevant to Africans, their theology, however, was to a large extent initially determined by the influence of the initial missionaries, an influence perpetuated by the impact contemporary American Pentecostal televangelists and preachers exercise on the African Pentecostal movement. In Africa as well, to speak of 'Pentecostal Theology' may seem to be a contradictio in terminis because 'theology' was initially critiqued, leading to the perception that the movement (at least in the first decades of its existence) was anti-intellectualist. As demonstrated, a survey of the writings of early authors in the movement illustrates that its seeming anti-intellectualistism can be explained historically in terms of the restorationist motif that justifies its origins and the expectation that it would introduce the second coming of Christ, that was perceived to have been distorted in the fourth century CE by creedalism, by the perceived danger that theological reflection can stand in the Spirit's way, and the potential of the mind to prevent believers from entering the spiritual dimension that defines a charismatic life. Firstgeneration voices explain that Pentecostalism was a movement of considerable diversity and creativity, a pluralistic score of spiritual insights from charismatic experiences that could not be reduced to a simple and singular shared religious tune (Jacobsen 2003:353).

\section{Future of Pentecostal Theology}

The history of theological development within the Pentecostal movement could be broadly classified in terms of three periods, an early period characterised by revivalism and the attempt to verbalise its experiences with a proliferation of publications (Noel 2007:87), a second period starting with the end of the Second World War and characterised by a search for acceptance and respectability by the community and government, leading to alliances with fundamentalist Evangelicals and the resultant conservative theological viewpoints (Karkkainen 1998:80), and a third era starting in the 1970s (Nel \& Janse van Rensburg 
2016:2) with new interest in pneumatology and hermeneutics, and later on narrative theology, missiology, healing and exorcism, the role of women in ministry, spiritual formation, and oneness theology (Mittelstadt 2010:81-112).

The fact is, contemporary Pentecostals have their own ethos to bring to the theological table (Cross 2000:29) out of their own experience with God. Pinnock (2000:9), for instance, refers to some important features of Pentecostal spirituality that he believes render them uniquely prepared to construct a theology that can make a significant contribution to the modern debate. Their spirituality is dynamic, and not caught up in exclusive rationalistic categories, allowing them to understand the relationality of God more than their 'paleoReformed' counterparts (as stereotyped by Pinnock 2000:10). This way of doing theology can be linked to patristic theology that was less concerned with dialectics and more with experience, a theology developed not from the scholar's cathedra but on the kneeling bench, growing from the ancient practice of lectio divina and ending in contemplation and loving union with God (Cunningham 1992:30). However, their experience-based spirituality should intentionally result in a reflection-based theology (Cross 2000:33), something that does not always happen. Pentecostals also have a sense of time and place that allows them to understand theology as a human construction related to a specific time, not in itself an eternal gift relevant for all times that functions as though it has been dropped from heaven. Their hermeneutical viewpoint compels them to allow for ongoing direct encounters with the God in the Bible, and in the same tradition as described in the Bible (Hollenweger, 1988:336; Mittelstadt, 2004:2). They view the Bible as a sign-post showing the way toward an encounter with God. Relevant knowledge about God is not found in the Bible; relational knowledge (in the sense of the Hebrew yada) is only found in the experience of a personal relationship with God. The Pentecostal view of truth is not propositional truth but orthodoxy-orthopraxy-orthopathy serves as the function, purpose, structure and essence of truth (Johns, 1995:92). The Bible is viewed in a dual sense, to create the expectation of an encounter with God and provide the language to describe those charismatic experiences.

When they read the Bible, Pentecostals take the 'natural' sense of the narrative, and emphasise that narratives form the most prominent part of the Bible (approximately sixty per cent) while these narratives are supposed to happen again in contemporary times. The Bible is the story world of God interacting with humans; Pentecostals tend to engage the narratives literally and existentially (Pinnock 2000:7). They are bold in their faith that supernatural interventions will happen in their world in the same way as described in the Bible. And when they repeatedly experience God's interventions, they start developing a theology; theology follows experience and not the other way around (Pinnock 2000:9). Pentecostal theological understanding exists within the touch field between biblical pronouncements and the existential reality of their lives, leaving little room for philosophical speculations about God. Their God teems with existential meaning and life because he interacts on a daily basis with his children and intervenes in their world.

It is imperative that Pentecostal Theology does not betray this dynamic approach by creating a model of God's static perfection rooted in essentially non-Christian (essentially Greek) thought (Pinnock 2000:21), in imitation of what happened in a part of the early church. In other words, the movement of the Spirit may not be quenched by theological reflection within a rationalistic vacuum, devoid of the breath of the Spirit. Bowdle (2000:9) emphasises that good theology is presupposed by Christ's command to love God with your whole mind (Matt 22:37), leading to theological reflection infused with the experience of God through his Spirit, radically shifting the loci communes and theological method within Pentecostalism. Pentecostals are not evangelicals who speak in tongues (Cross 2000:34); 
Pentecostal Theology reflects the reality of God's encounter with humans, flavoring the totality of theological endeavour (Menzies 1979:15). Their spirituality determines their theological method because mind and affections are (or should be) united in their spirituality (Land 1993:25-27), overcoming the modernist split between reason and emotions, and cognition and experience, as Barth (1963:55) already explained when he declared that evangelical theology itself can only be pneumatic, spiritual theology. The community of Spirit and Word functions as a worshipping, witnessing, reflective whole, with the liturgical life of the community at its heart (Land 1993:34). While theology cannot be equated with spirituality, it cannot be divorced from it in order to avoid the twin errors of limiting theology to a commentary on experience and misunderstanding God and his relationship to his people. Theology should be cognitive reflection joined to the thoughtful spiritual and charismatic dimension of experience; how one experiences God influences and determines the way one reflects on God (Cross 2000:35). "Experience is primary over theory and must show up in any cognitive packaging" (Pinnock 2000:10). The Spirit is integrated in theological method, making Pentecostal Theology dynamic not rationalistic (Pinnock 2000:4).

The contention is stated here that the success of the Pentecostal movement should be ascribed to this dynamic relational character. Fact is, the Pentecostal movement developed into a significant religious movement. ${ }^{6}$ Pentecostal Theology is a second-order reflection on the primary narrative of God in revelation as found in Scriptures, coordinated and joined with a reflection on the relational experience of God in Pentecostals' lives (Migliore 1991:9; Grenz 1993:78). The narrative of Scripture offers the original source of reflection, but Pentecostal Theology cannot remain merely a restatement of biblical narrative or propositional truths in contemporary language. Its theology should always be shaped by the language of the Bible but at the same time it is recreated within the life-receiving and lifegiving community of faith created by the Spirit as part of the kingdom of God. While theology derives its language and grammatical concepts from the narratives of the past, theology follows when the Spirit confronts a person with the reality of God in the narrative and in one's current situation, affecting one's cognitive response to the event (Pinnock 1990:186).

\section{Conclusion}

It has been argued that the Pentecostal movement's perceived anti-intellectualism should be understood in terms of its historical function while the contemporary movement is contributing in a unique manner to theological enterprise. Its theology is based on the experience of God's reality, described in the terms provided by biblical narratives about similar encounters between God and human beings, leading to a spirituality that occupies the affections as well as the minds of its practitioners. Their theology has traditional elements that it shares with other traditions although Pentecostalism's spirituality requires that its theology should be based on first-hand experiences with God, while at the same time it defines some doctrines in another manner due to the Spirit meeting the fellowship of believers.

6 Pentecostalism grows at a rate of 19 million a year (Barrett 1998:50). By 2006 the number of Pentecostals and charismatics exceeded 580 million (Blumhofer 2006:21), ensuring that Pentecostalism was the fastest growing branch of Christianity worldwide (Turnage 2003:6). McGee (2012:35) reckons that at the current rate of growth, there will be 1 billion Pentecostals by 2025, with most of them living in Asia, Africa, and Latin America (McGee 2012:35), presenting the southward swing of the Christian centre of gravity (Anderson 2003:1). 


\section{BIBLIOGRAPHY}

Anderson, AH 2003. “Towards a Pentecostal Missiology for the Majority World.” Paper presented at the International Symposium on Pentecostal Missiology, Asia-Pacific Theological Seminary, Baguio City, Philippines, 1-19.

Anonymous, April 1907. Untitled. The Apostolic Faith 1(7):1.

Anonymous, September 1907a. Untitled. The Apostolic Faith 1(10):2-3.

Anonymous, September 1907b. "To the Baptized Saints." The Apostolic Faith 1(9):2.

Asamoah-Gyadu, JK 2005. “'Born of Water and the Spirit': Pentecostal/Charismatic

Christianity in Africa", in Kalu, OU (ed.), African Christianity: An African Story,

388-409. University of Pretoria, Pretoria. Perspective on Christianity Series 5, 3.

Barrett, D 1998. “A Century of Growth”. Christianity Today 42(16):50-51.

Barth, K. 1963. Evangelical Theology: An Introduction. Tr. G Foley.

Grand Rapids: Eerdmans.

Bowdle, DN 2000. "Informed Pentecostalism: An alternative Paradigm", in Cross, T \&

Powery, E (eds.). The Spirit and the Mind: Essays in Informed Pentecostalism, 9-19.

Lanham: University Press of America.

Blumhofer, E 2006. “Azusa Street Revival”. Christian Century 123(5):20-22.

Conn, C.W. 1977. Like a Mighty Army: A History of the Church of God, 1886-1976.

Cleveland: Pathway.

Conn, CW 1988. "Church of God (Cleveland, Tenn.) in Canada", in Burgess, SM \&

McGee, GB (eds.). Dictionary of Pentecostal and Charismatic Movements, 202.

Grand Rapids: Zondervan.

Cross, TL 2000. "The Rich Feast of Theology: Can Pentecostals bring the main Course or only the Relish?” Journal of Pentecostal Theology 16:27-47.

Cunningham, LS 1992. Thomas Merton: Spiritual Master. The Essential Writings.

New York: Paulist.

Enyinnaya, JO 2008. "Pentecostal Hermeneutics and Preaching: An Appraisal." Ogbomoso Journal of Theology XIII(1):144-153.

Gelpi, D 1978. Experiencing God: A Theology of Human Emergence. New York: Paulist.

Goff, JR 1988. "Parham, Charles Fox", in Burgess, SM \& McGee, GB (eds.) Dictionary of Pentecostal and Charismatic Movements, 660-661. Grand Rapids: Zondervan.

Grenz, S 1993. Revisioning Evangelical Theology: A fresh Agenda for the 21st Century. Downers Grove: InterVarsity.

Hollenweger, WJ 1986. “After Twenty Years' Research on Pentecostalism.”

Guest editorial. International Review of Missions 75(297):3-12.

Hollenweger, WJ 1988. The Pentecostals. Revised edition. London: SCM.

Hollenweger, WJ 1992. "The Critical Tradition of Pentecostalism.” Journal of Pentecostal Theology 1:7-17.

Jacobsen, D 2003. Thinking in the Spirit: Theologies of the early Pentecostal Movement. Bloomington: Indiana University Press.

Jacobsen, D 2006. A Reader in Pentecostal Theology: Voices from the First Generation. Bloomington: Indiana University Press, 
Johns, CB1998. "What can the Mainline Learn from Pentecostals about Pentecost?" Journal for Preachers. Lent:3-7.

Johns, JD 1995. "Pentecostalism and the Postmodern Worldview." Journal for Pentecostal Theology 7:73-96.

Karkkainen, V-M 1998. "Pentecostal Hermeneutics in the Making: On the Way from Fundamentalism to Postmodernism." Journal of European Pentecostal Theological Association XVIII:76-115.

King, JH 1937. “The Foundation Eternal.” Editorial. Pentecostal Holiness Advocate, May 27:1.

Land, S 1993. Pentecostal Spirituality: A Passion for the Kingdom. JPTSup. 1. Sheffield: Sheffield Academic Press.

McGee, GB 2012. "Early Pentecostal Missionaries: They went Everywhere preaching the Gospel", in McClung, G (ed.) Azusa Street and Beyond: Missional Commentary on the global Pentecostal/Charismatic Movement, 35-40. Revised edition. Alachua: Bridge-Logos.

Menzies, W 1979. "Synoptic Theology: An Essay on Pentecostal Hermeneutics." Paraclete 13:14-15.

Migliore, D 1991. Faith Seeking Understanding: An Introduction to Christian Theology. Grand Rapids: Eerdmans.

Mittelstadt, MW 2004. The Spirit and Suffering in Luke-Acts: Implications for a Pentecostal Theology. London, New York: T\&T Clark.

Mittelstadt, MW 2010. Reading Luke-Acts in the Pentecostal Tradition. Cleveland: CPT. Myland, DW 1910. The latter Rain Covenant and Pentecostal Power with Testimony of Healings and Baptism. Chicago: Evangel.

Myland, DW 1911. The Revelation of Jesus Christ: A Comprehensive Harmonic Outline and Perspective View of the Book. Chicago: Evangel.

Naňez, R. 2005. Full Gospel, Fractured Minds: A Call to use God's Gift of the Intellect. Grand Rapids: Zondervan.

Nel, M 2016. “'Rather Spirit-filled than Learned!' Pentecostalism's Tradition of AntiIntellectualism and Pentecostal Theological Scholarship”. Verbum et Ecclesia 37(1), a1533. http:// dx.doi.org/10.4102/ve. v37i1.1533.

Nel, M \&. Janse van Rensburg, F 2016. "Integrating Spirituality and Rationality the Long and Arduous Journey of the Historical Development of Theological Training in the Apostolic Faith Mission of South Africa”. In die Skriflig 50(2), a1943. http://dx.doi. org/10.4102/ids.v50i2.1943.

Noble, EM 1991. Like as of Fire: Newspapers from the Azusa Street World Wide Revival. Washington: Middle Atlantic Regional.

Noel, BD 2007. "Pentecostal and Postmodern Hermeneutics: Comparisons and Contemporary Impact". DTh Dissertation, University of South Africa.

Parham, CF [1902]1944. Kol kare bemidbar: A Voice crying in the Wilderness. Baxter Springs: Robert L Parham.

Parham, CF 1920. The Everlasting Gospel. Baxter Springs: Charles F Parham.

Pinnock, CH 1990. Tracking the Maze: Finding our Way through Modern Theology from an Evangelical Perspective. San Francisco: Harper. 
Pinnock, CH 2000. "Divine Relationality: A Pentecostal Contribution to the Doctrine of God." Journal of Pentecostal Theology 16:2-26.

Robinson, EB 1988. "David Wesley Myland”, in Burgess, SM \& McGee, GB (eds.)

Dictionary of Pentecostal and Charismatic Movements, 632-633.

Grand Rapids: Zondervan.

Rogers, J 1981. "The Search for System: American Theology in the 1980s.” Theology News and Notes, December 1981:4.

Seymour, WJ September 1906. "The Apostolic Faith Movement.” The Apostolic Faith 1(1):2.

Seymour, WJ October 1906. “The Pentecostal Baptism Restored.” The Apostolic Faith $1(2): 1$.

Seymour, WJ December 1906. Untitled. The Apostolic Faith 1(4):1.

Seymour, WJ 1915. The Doctrines and Disciplines of the Azusa Street Apostolic Faith Mission of Los Angeles, cal. with Scripture Readings. Los Angeles:

William J Seymour.

Spittler, RP 1983. "Suggested Areas for further Research in Pentecostal Studies." Pneuma Fall:39-56.

Spittler, RP 1985. "Scripture and the Theological Enterprise: View from a Big Canoe", in Johnston, RL (ed.). The Use of the Bible in Theology/Evangelical Options, 56-77. Atlanta: John Knox.

Spurling, RG 1920. The Lost Link. Turtletown: RG Spurling.

Synan, HV 1988. "Seymour, William Joseph”, in Burgess, SM \& McGee, GB (eds.). Dictionary of Pentecostal and Charismatic Movements, 778-781. Grand Rapids: Zondervan.

Tomlinson, AJ 1913. The Last Great Conflict. Cleveland, Tenn.: Press of Walter E Rodgers. http://www.churchofgod.org/heritage/HistoryTomlinson.pdf - accessed 2016-10-26.

Tull, JE 1984. "Landmark Movement", in Hill, SS (ed.) Encyclopedia of Religion in the South, 399-401. Macon: Mercer University Press.

Turnage, M 2003. "The Early Church and the Axis of History and Pentecostalism facing the 21st Century: Some Reflections." Journal of the European Pentecostal Theological Association 223:4-29.

Vallarie, P 1983. Holy War and Pentecostal Peace. New York: Seabury.

Wacker, G 2001. Heaven Below: Early Pentecostals and American Culture. Cambridge, MA: Harvard University Press.

Yeung, T 2011. "The Characteristics of William Seymour's Sermons: A Reflection of Pentecostal Ethos." Asian Journal of Pentecostal Studies 14(1):57-73. 